\title{
FOREST FIRE RISK ASSESSMENT USING GIS AND AHP INTEGRATION IN BUCAK FOREST ENTERPRISE, TURKEY
}

\author{
ÇOBAN, H. O. ${ }^{1 *}-$ ERDIN, C. ${ }^{2}$ \\ ${ }^{I}$ Department of Forest Engineering, Faculty of Forestry, Isparta University of Applied Sciences, \\ 32260 Isparta, Turkey \\ ${ }^{2}$ Department of Business Administration, Faculty of Economic and Administrative Sciences, \\ Ylldız Technical University, Istanbul, Turkey \\ ${ }^{*}$ Corresponding author \\ e-mail: oguzcoban@isparta.edu.tr \\ (Received $2^{\text {nd }}$ Oct 2019; accepted $8^{\text {th }}$ Jan 2020)
}

\begin{abstract}
Forest fires create an increasingly severe and negative impact on ecosystem services such as carbon storage, climate balancing and water supply as a result of global warming threatening our planet. One of the steps to fight forest fires is to perform a risk assessment. Forest fire risk assessment allows the identification of locations at high risk of forest fire and estimate its sphere of influence. In this way, it provides decision-making support to the fire-fighting organization. The purpose of this study was to conduct a forest fire risk assessment in forests located in Bucak Forest Enterprise in Turkey that is vulnerable to fire at the first degree. In the study, the weights of the criteria that lead to fire risk were computed with Analytic Hierarchy Process (AHP). The risk classes of the criteria were exported to the raster layer of the Geographical Information System (GIS). The results showed that $25 \%$ of forests in Bucak region were at high risk, while $32 \%$ were at medium fire risk. We believe that the approach adopted in this study may contribute to forest fire risk assessments and risk mapping of Mediterranean forest ecosystems that have similar climate, topographic structure and vegetation.
\end{abstract}

Keywords: Mediterranean forests, fire risk factors, fire risk mapping, spatial analysis, fire sensitivity

\section{Introduction}

Fire is an incident that leads to very severe changes in forest ecosystems (Naderpour et al., 2019). Forest fire poses a great danger to human life and environment (McKenzie et al., 2014; Garbolino et al., 2017). The European statistics demonstrate that 500 thousand hectares of forests are destroyed on average every year due to fire (EC, 2017). It is argued that the number of forest fires will increase in the future owing to climate change, changes in land use and forestry policies (González-De Vega et al., 2016; García-Llamas et al, 2019).

The Mediterranean forest ecosystems are resistant to fire (Pausas and Vallejo, 1999; Calvo et al., 2008); nevertheless, it is important to prevent fire before it reaches a dramatic point and fight against fire for social life and economy. We hope that forest fire risk assessments and organization of the efforts according to the risk levels identified will provide positive inputs for success in anti-forest fire efforts.

The forests located in the Mediterranean Region in the south of Turkey are vulnerable to fire; therefore, fire occurs very frequently in the forest ecosystems in this region. The statistics of the General Directorate for Forestry (GDF, 2019) reveal that on average more than 500 forest fire on average occur every year as a result of which more than 10000 hectares of forests are destroyed (Figure 1). As regards the causes of these fires, almost $90 \%$ of them are manmade (Figure 2). 


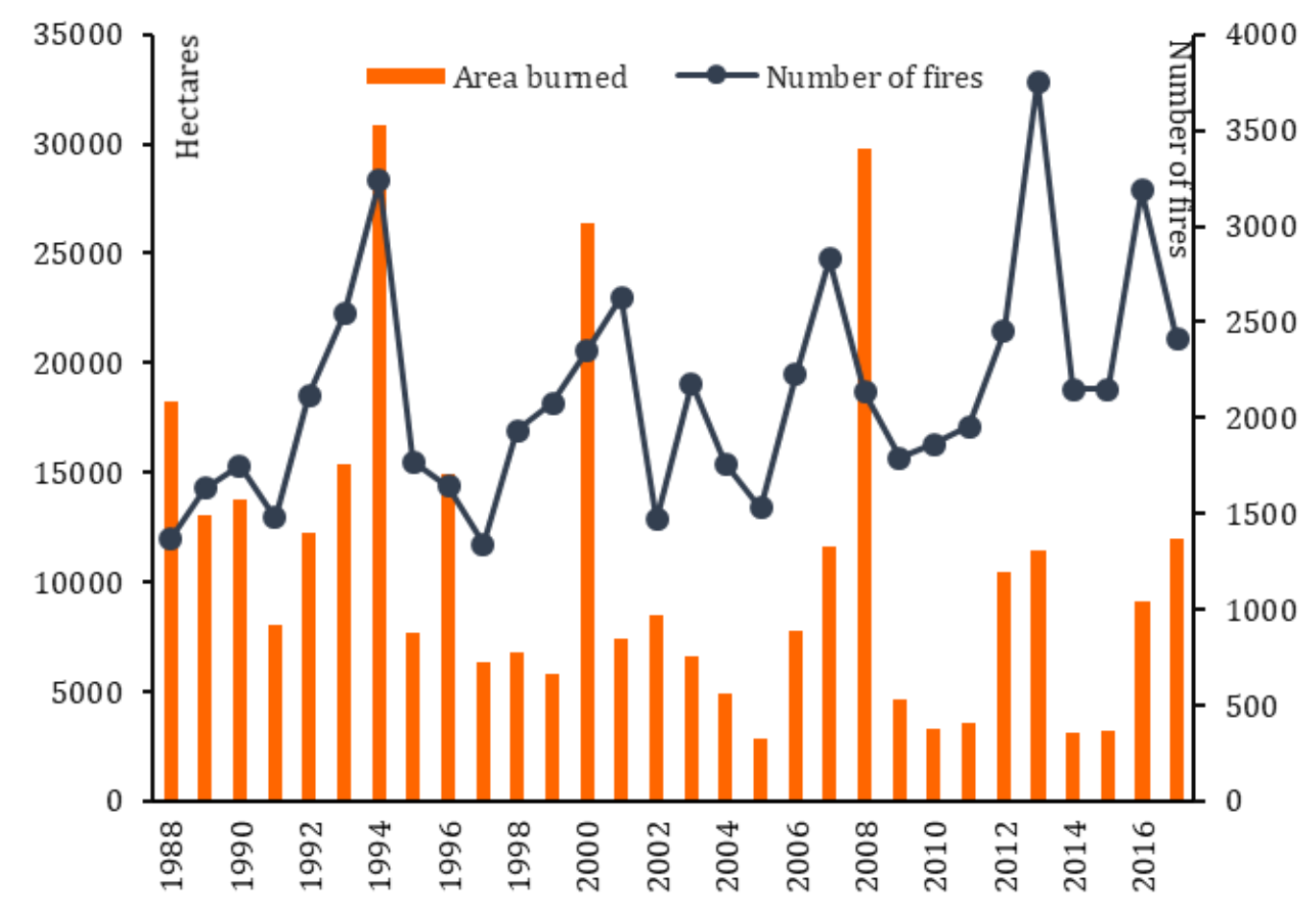

Figure 1. The number of forest fires in Turkey between years 1988-2017 and the area of forests burned (GDF, 2019)

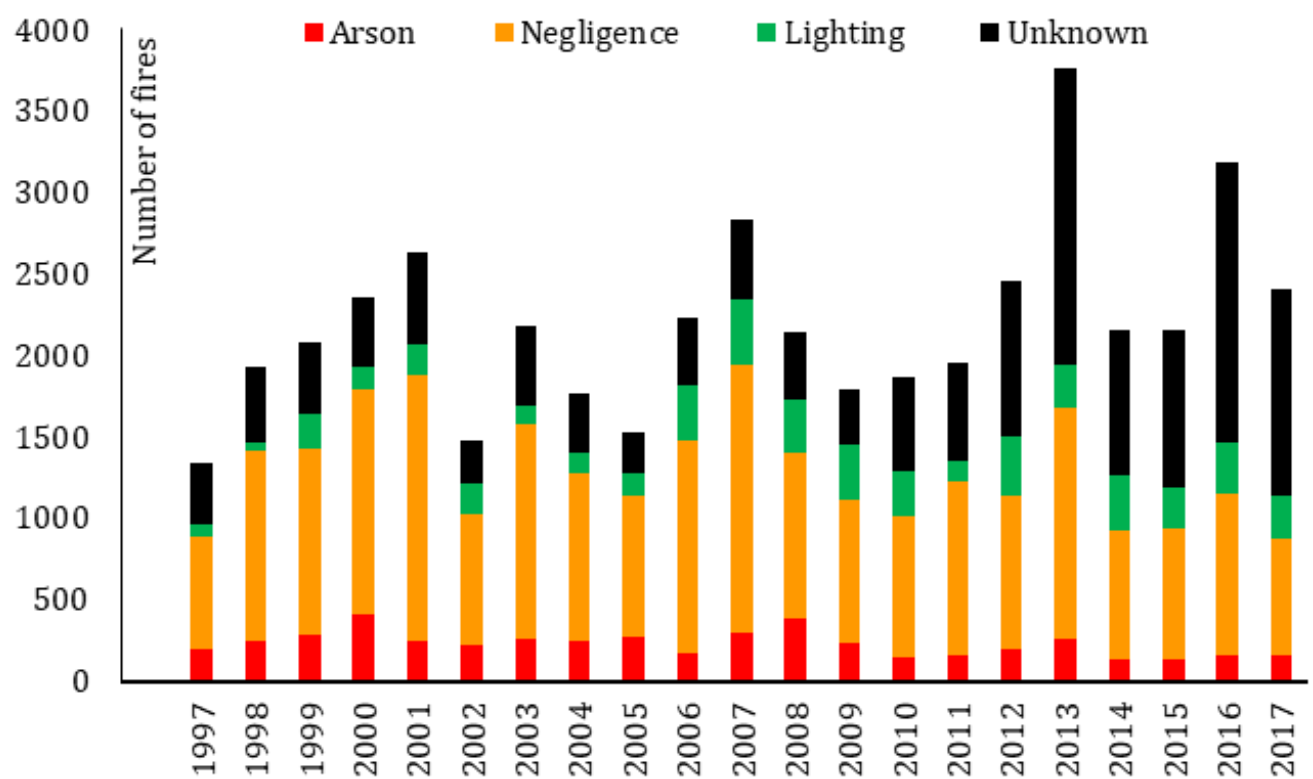

Figure 2. The causes of forest fires in Turkey between years 1997-2017 (GDF, 2019)

Forest lands are managed according to the decisions based on multiple criteria decision making (MCDM) methods. Particularly, decisions taken to prevent, fight and monitor forest fires are the most important ones. The location of fire lookout towers as well as 
deployment area and number of first response teams are also decided with MCDM methods alone or MCDM in combination with GIS (Fisher and Keida, 1990; Korkmaz, 2004; Akay and Şakar, 2009; Akay and Şahin, 2019).

The objective of this study was to determine and map the fire risk zones of a forest ecosystem in Bucak Forest Enterprise in Turkey that is vulnerable to fire at the first degree. We are of the opinion that the best method to fight forest fires is to use the experts' knowledge, experience and predictions. In this context, the weights of the criteria for forest risk were determined with Analytic Hierarchy Process (AHP). GIS was also used as a support to determine the fire risk zones in the study area because one of the main goals of GIS is to support spatial decision making process (Simon, 1960). In this way, the spatial analysis of the criteria related to human behaviours, climate, vegetation and topography was conducted in GIS by using the risks computed for the study area with AHP. As a result, the "forest fire risk zones" of the forests in Bucak region were determined and mapped.

\section{Multi-criteria decision making and AHP}

Multi-criteria decision analysis is defined as a matrix to choose the best alternative from several potential candidates and in case of conflicting criteria to solve problems, which is called decision matrix. Various MCDM methods have been developed since 1960 for solving decision making problems (Malczewski and Rinner, 2015). What is important at this point is to determine which multiple-criteria decision-making method is the best to solve a certain multiple-criteria decision making problem (Guarini et al., 2018).

AHP is one of the most comprehensive methods of multi-criteria decision analysis, which is a digital approach (Kumar and Garg, 2017). It is a powerful and flexible decision-making theory to rank different features (Belhadi et al., 2017). AHP is a measurement theory based on pairwise comparison. In its comparisons, it uses absolute judgment scale to represent the measurement of a scale for a feature whereas the linguistic judgments related to the assessment of people are usually uncertain in real life and it is not realistic to represent them with exact values (Ishizaka and Nguyen, 2013). This method developed by Saaty (1980) is widely used to solve multiple-criteria decision making problems. It allows modelling in a hierarchical structure that describes the relationship between the main target of the criterion, sub-criteria and alternatives in solving a complex decision making problem. In another word, AHP is a method that synthesizes knowledge, experience, views and feelings of an individual (Kuruüzüm and Altan, 2001).

A priority vector is obtained in the pairwise comparison matrix. The priority vector is the "eigenvector" of the matrix. The decision priorities called as weights attributed to the qualitative features are determined in the form of eigenvector of the pairwise comparison matrix (Jain and Naq, 1996). The "relative importance" of the criteria is determined from the lowest ranking criteria to the highest criteria using the eigenvector. The stages of solving a multi-criteria decision making problem with AHP include the identification of the problem, observation of the system, creation of the hierarchical structure, control of consistency, determination of the priority values and conclusion (Saaty and Vargas, 2012).

\section{GIS-based approach}

GIS is a valuable tool that collects, processes and analyses spatial data with its structural and functional components and offers support to the decision-making process 
(Chang, 2016). While it is commonly used in disciplines examining spatial data, many users in forestry sector also prefer it. The GIS-based studies regarding the identification of forest fire risk zones showed that the interactive structure of GIS was a powerful source (Jaiswal et al., 2002; Yomralığlu, 2015). A formulation was developed to calculate the fire risk index values using vegetation type, proximity to settlements, proximity to roads and gradient variables. The variables were categorized according to their vulnerability to fire and every category was given a specific value (You et al., 2017). To determine the fire risk zones, the factors and sub-factors were determined using AHP, while spatial distribution of the risk categories were produced using GIS computation in proportion to the weights of these factors.

In Turkey, there are studies that have determined fire risk categories based on GIS (Sağlam et al., 2008; Küçük et al., 2017) and combined use of GIS and AHP (Güngöroğlu, 2017; Akbulak et al., 2018). AHP appears to be a method used for determining factors and their weights as regards fire risk. The determination of weights of main factors and sub-factors, determination of risk categories of the sub factors and setting values for those categories are all done by consulting an expert opinion. Besides using multi-criteria decision-making methods when determining these factors, the fire statistics observed for many years are also relevant. It is therefore possible to adapt the information from the relevant literature to the special characteristics of the field.

\section{Materials and Methods}

\section{Study area}

This study was conducted in Bucak Department of Forestry located in Western Mediterranean Region of Turkey with coordinates of $37^{\circ} 12^{\prime} 08^{\prime \prime}-37^{\circ} 34^{\prime} 20^{\prime \prime}$ North latitude and $30^{\circ} 14^{\prime} 02^{\prime \prime}-30^{\circ} 50^{\prime} 53^{\prime \prime}$ East longitude (Figure 3). As for the topographic structure of the region; the minimum, maximum and average altitudes are $72 \mathrm{~m}, 2317 \mathrm{~m}$ and $900 \mathrm{~m}$, respectively. Average slope is $26 \%$. In addition to the Mediterranean climate, continental climate can also be observed. In this region, the mean temperature was $15^{\circ} \mathrm{C}$, the average maximum temperature was $21^{\circ} \mathrm{C}$ and the average minimum temperature was $9^{\circ} \mathrm{C}$ from 1932 to 2018 . Summer is arid and warm (maximum temperature $43^{\circ} \mathrm{C}$ ) and winter is cold and rainy (minimum temperature $-14^{\circ} \mathrm{C}$ ). The annual mean precipitation is $450 \mathrm{~mm}$ whereas it is $15 \mathrm{~mm}$ on average in summer. The relative mean humidity in summer is $40 \%$ and while the dominant wind direction is south (GDF, 2019; Worldclim, 2019).

The size of the field is 141,057 ha, and $71 \%$ is forestland. $38.64 \%$ of the forestland is unproductive with crown closure under 10\%. In the region's forests, 73013 ha of land consist of coniferous species, while 19621 ha consist of deciduous species. Approximately $72 \%$ of the coniferous species consists of Pinus brutia Ten. and Pinus nigra Arnold which are relatively sensitive to fire.

Bucak Department of Forestry under Isparta Regional Directorate of Forestry is highly sensitive regarding forest fires. From 2008 to 2018 when the forest fires were investigated in the region, the highest number of fires was observed in this region with $0.9 \times 10^{-3}$ per hectare. According to the same statistics, $85 \%$ of the forest fires in the region started during daytime, from 7:00 to 19:00 (IRDF, 2019). Within the fire-fighting organization, there are 4 lookout towers, 5 fire first response teams, 11 water trucks, 1 grader, 1 dozer and 10 fire pools. 


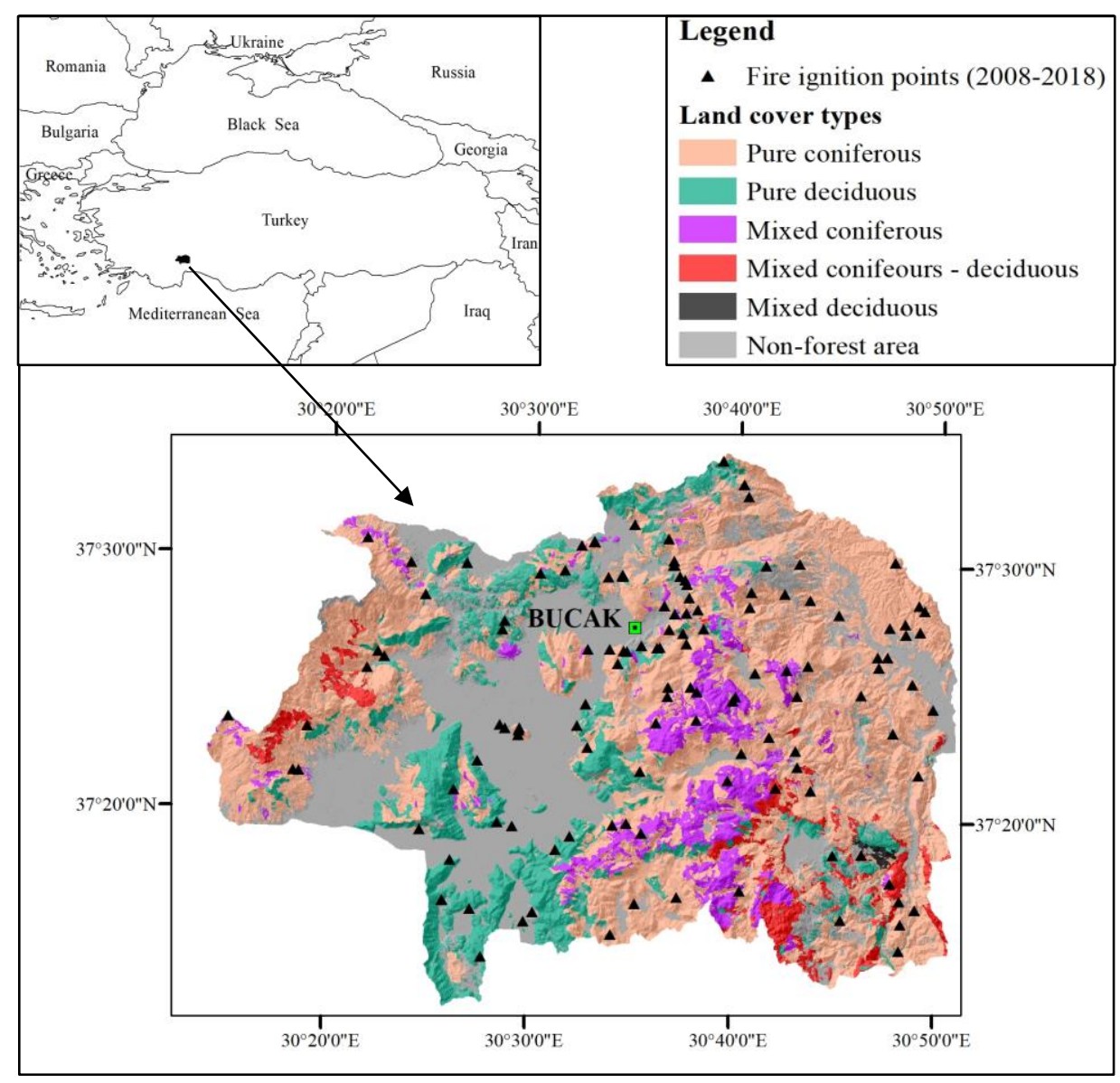

Figure 3. Spatial location of the study area

\section{Dataset}

Shuttle Radar Topography Mission (SRTM; version 3) data was used to create digital elevation model of the study field. This data was downloaded from https://gdex.cr.usgs.gov/gdex/ at a resolution of 1 arc-second (30 meters) from a global dataset (USGS, 2019). Altitude, slope and aspect maps were produced from the digital elevation data. Forest management plan maps for the years 2007 to 2017 of Bucak Forest State Enterprise were geographically categorized in ArcGIS environment into vegetation type, stand development period, crown closure, cultivated areas and settlements. Digital vector data of power lines and roads were provided by GIS department of Isparta Regional Directorate of Forestry. Climate data from 1970 to 2000 was obtained from http://worldclim.org/. In this platform where global climate data are presented, raster data with a resolution of approximately $1 \mathrm{~km} \times 1 \mathrm{~km}$ was used. ArcGIS (version 10.2.2) software was used for GIS applications.

\section{Methods}

\section{Computing the criteria weights using AHP}

In the first stage of AHP, the decision problem was structured hierarchically. In the second step of AHP, pairwise comparisons and the option matrix were established. The pairwise comparison is an innate human ability and focuses on the relationship between 
pairwise data groups, thereby significantly reducing the complexity of decision-making (Saaty and Saaty, 2019). Pairwise comparison method consists of three steps: a) Forming the pairwise comparison matrix in all steps of the hierarchy, b) Computing the weights for each hierarchy, c) Determining the consistency index.

Hierarchically structuring the decision problem:

- Determining the criteria: Criteria are determined by expert opinion, relevant data sources and experiences of forest fire experts (Criteria and their definitions are shown in Table 1).

- The hierarchical structure of the decision problem was created (Saaty and Vargas, 2012).

- For pairwise comparisons to be evaluated by decision-makers to determine the criteria weights, pairwise comparison tables were formed (Saaty and Saaty, 2019).

- In pairwise comparisons, experts perform comparisons using the fundamental scale (Saaty, 1990).

Decisions are made by agreement based on two comparison scales or the geometric mean method can be used in the event of three different scales (Van den Honert and Lootsma, 1996; Bolloju, 2001).

Table 1. Criteria and definitions

\begin{tabular}{|c|c|c|}
\hline Criteria & Sub-criteria & Definition \\
\hline $\mathrm{K}_{1}$ : Human behaviour & $\begin{array}{l}\mathrm{K}_{11} \text { : Proximity to settlements } \\
\mathrm{K}_{12} \text { Proximity to the road network } \\
\mathrm{K}_{13} \text { : Proximity to the cultivated areas } \\
\mathrm{K}_{14} \text { : Proximity to the power lines }\end{array}$ & $\begin{array}{l}\text { Settlements in and around the forest } \\
\text { Roads in and around the forest } \\
\text { Cultivated areas in and around the forest } \\
\text { Power lines in and around the forest }\end{array}$ \\
\hline $\begin{array}{l}\mathrm{K}_{2}: \text { Structural } \\
\text { characteristics of forests }\end{array}$ & $\begin{array}{l}\mathrm{K}_{21}: \text { Vegetation type } \\
\mathrm{K}_{22} \text { : Age of stand development } \\
\mathrm{K}_{23} \text { : Crown closure }\end{array}$ & $\begin{array}{l}\text { Fire sensitivity of tree species } \\
\text { Forest texture which is sensitive to fire } \\
\text { Shading rate of forest trees }\end{array}$ \\
\hline $\begin{array}{l}\mathrm{K}_{3} \text { : Topographic structure } \\
\text { of forests }\end{array}$ & $\begin{array}{l}\mathrm{K}_{31:} \text { Altitude } \\
\mathrm{K}_{32:} \text { Slope } \\
\mathrm{K}_{33} \text { Aspect }\end{array}$ & $\begin{array}{l}\text { Elevations of the forest } \\
\text { Forest slope } \\
\text { Dominant aspect of forest areas }\end{array}$ \\
\hline $\mathrm{K}_{4}:$ Climate data & $\begin{array}{l}\mathrm{K}_{41} \text { : Mean temperature of warmest quarter } \\
\mathrm{K}_{42} \text { : Precipitation of warmest quarter } \\
\mathrm{K}_{43} \text { : Mean wind speed of warmest quarter }\end{array}$ & $\begin{array}{l}\text { Mean temperature during fire season } \\
\text { Precipitation during fire season } \\
\text { Mean wind speed during fire season }\end{array}$ \\
\hline
\end{tabular}

After determining the criteria and completing pairwise comparisons, the comparison matrices of criteria and sub criteria are formed. By evaluating the comparison matrices, weights of criteria are computed. Consistency tests were applied to check the reliability of the matrices. In order to check the consistency of the matrix, consistency index and consistency rate are calculated (Saaty, 1980). The consistency index (CI) of the comparison matrix is calculated with the following formulation:

$$
C I=\frac{\lambda_{\max }-n}{n-1}
$$

where $\mathrm{CI}$ is consistency index, $\chi_{\max }$ is the largest eigenvalue, $\mathrm{n}$ is the number of criteria compare.

The consistency rate $(\mathrm{CR})$ is calculated with the following formulation:

$$
C R=\frac{\mathrm{CI}}{R I}
$$


where, $\mathrm{CI}$ is consistency index, $\mathrm{RI}$ is random index which depends on the number of criteria being compared. For example, for $\mathrm{n}=2,3,4$, and 5, RI $=0.00,0.52,0.89$ and 1.11 , respectively. CR $<0.10$ indicates a reasonable consistency level for pairwise comparisons. $\mathrm{CR} \geq 0.10$, however, indicates that the values in the pairwise comparison matrix should be reviewed and revise (Saaty, 1980).

\section{GIS-based evaluation and mapping}

The relevant literature for determining the risk categories of the sub criteria used to identify the fire risk zones was reviewed (Jaiswal et al., 2002; Sağlam et al., 2008; You et al., 2017). Jaiswal et al. (2002) developed a formulation for fire risk index, which is also suitable for the field's conditions. The special conditions of the field require customisation of the variables related to the fire risk values. For example, variables of latitude and vegetation differ considerably. The risk values of vegetation cover were listed by examining the fire sensitivity status of the target stands, which were distributed in the region. After defining the risk values for all stand types in the geographic database, the stands with the same risk values were combined and clustered.

The most fire sensitive tree species in the region were red pine and black pine stands (Neyişçi et al., 1996). The highest risk values were assigned to these stands. The variables of the distance between the road and the power lines and the distance between the settlements and the cultivated areas were determined according to the approach described by You et al. (2017) and values proposed by Şentürk (2018). Additionally, the distribution of 130 fire exit points in the zones which were produced at intervals of 0-25 m, 25-50 m, $50-100 \mathrm{~m}$ and $100 \mathrm{~m}$ farther from the road, power lines, settlements and cultivated areas were also evaluated. The climate data was calculated according to the approach proposed by You et al. (2017).

Raster layers were prepared and categorized according to the classes in Table 2. These raster layers were multiplied by their own criteria weight using the "raster calculator" available at ArcGIS software and fire risk values were achieved. These values were categorized (Jenks and Caspall, 1971) and fire risk zones were mapped.

\section{Results and Discussion}

\section{Forming of the comparison matrices of criteria and sub criteria in AHP}

The criteria indicated in Table 1 were evaluated by the experts according to the AHP comparison scale specified in Table 3 and the comparison scheme in Table 2. Comparison matrix of the criteria was formed (Table 3).

Similarly, the same steps were applied for the sub criteria and as a result, the comparison matrices of the sub criteria of the $\mathrm{K}_{1}, \mathrm{~K}_{2}, \mathrm{~K}_{3}, \mathrm{~K}_{4}$ criteria were calculated (Tables 4-7).

\section{Evaluation of comparison matrices}

To normalize the pairwise comparisons of the criteria,

- All columns are summed up (Table 3).

- Each column element in Table 3 is divided into column sum (Table 8).

- Total rows are calculated (Table 8).

- Average of row sum (w) is found (Table 8). 
Table 2. Variables and risk values to be used in the calculation and mapping of fire risk

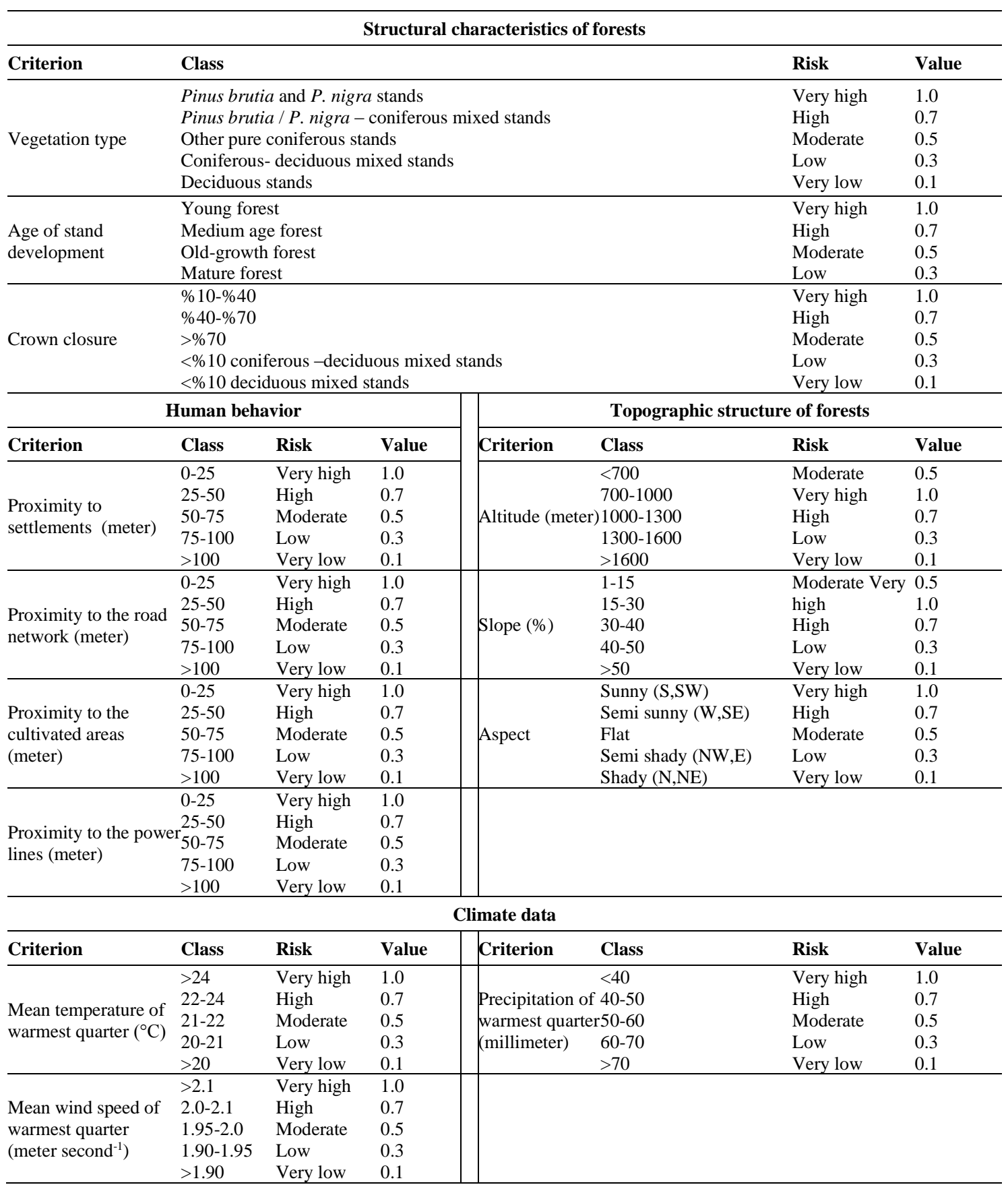

Table 3. Comparison matrix of the criteria

\begin{tabular}{c|c|c|c|c}
\hline & $\mathbf{K}_{\mathbf{1}}$ & $\mathbf{K}_{\mathbf{2}}$ & $\mathbf{K}_{\mathbf{3}}$ & $\mathbf{K}_{\mathbf{4}}$ \\
\hline $\mathbf{K}_{\mathbf{1}}$ & 1 & 3 & 5 & 7 \\
$\mathbf{K}_{\mathbf{2}}$ & 0.333 & 1 & 3 & 5 \\
$\mathbf{K}_{\mathbf{3}}$ & 0.200 & 0.333 & 1 & 1 \\
$\mathbf{K}_{\mathbf{4}}$ & 0.143 & 0.200 & 1 & 1 \\
\hline Total & 1.676 & 4.533 & 10 & 14 \\
\hline
\end{tabular}

$\mathrm{K}_{1}$ : Human behaviour, $\mathrm{K}_{2}$ : Structural characteristics of forests, $\mathrm{K}_{3}$ : Topographic structure of forests, $\mathrm{K}_{4}$ : Climate data 
Table 4. Comparison matrix of the sub-criteria of $K_{I}$

\begin{tabular}{l|c|c|c|c}
\hline & $\mathbf{K}_{\mathbf{1 1}}$ & $\mathbf{K}_{\mathbf{1 2}}$ & $\mathbf{K}_{\mathbf{1 3}}$ & $\mathbf{K}_{\mathbf{1 4}}$ \\
\hline $\mathbf{K}_{\mathbf{1 1}}$ & 1 & 0.2 & 3 & 4 \\
$\mathbf{K}_{\mathbf{1 2}}$ & 5 & 1 & 9 & 7 \\
$\mathbf{K}_{\mathbf{1 3}}$ & 0.333 & 0.111 & 1 & 2 \\
$\mathbf{K}_{\mathbf{1 4}}$ & 0.25 & 0.143 & 0.5 & 1 \\
\hline
\end{tabular}

$\mathrm{K}_{11}$ : Proximity of settlement, $\mathrm{K}_{12}$ : Proximity of road network, $\mathrm{K}_{13}$ : Proximity of cultivated areas, $\mathrm{K}_{14}$ : Proximity of power lines

Table 5. Comparison matrix of the sub-criteria of $K_{2}$

\begin{tabular}{c|c|c|c}
\hline & $\mathbf{K}_{\mathbf{2 1}}$ & $\mathbf{K}_{\mathbf{2 2}}$ & $\mathbf{K}_{\mathbf{2 3}}$ \\
\hline $\mathbf{K}_{\mathbf{2 1}}$ & 1 & 3 & 5 \\
$\mathbf{K}_{\mathbf{2 2}}$ & 0.333 & 1 & 4 \\
$\mathbf{K}_{\mathbf{2 3}}$ & 0.2 & 0.25 & 1 \\
\hline
\end{tabular}

$\mathrm{K}_{21}$ : Vegetation type, $\mathrm{K}_{22}$ : Age of stand development, $\mathrm{K}_{23}$ : Crown closure

Table 6. Comparison matrix of the sub-criteria of $K_{3}$

\begin{tabular}{l|c|c|c}
\hline & $\mathbf{K}_{\mathbf{3 1}}$ & $\mathbf{K}_{\mathbf{3 2}}$ & $\mathbf{K}_{\mathbf{3 3}}$ \\
\hline $\mathbf{K}_{\mathbf{3 1}}$ & 1 & 5 & 3 \\
$\mathbf{K}_{\mathbf{3 2}}$ & 0.2 & 1 & 0.333 \\
$\mathbf{K}_{\mathbf{3 3}}$ & 0.333 & 3 & 1 \\
\hline
\end{tabular}

$\mathrm{K}_{31}$ : Altitude, $\mathrm{K}_{32}$ : Slope, $\mathrm{K}_{33}$ : Aspect

Table 7. Comparison matrix of the sub-criteria of $K_{4}$

\begin{tabular}{l|c|c|c}
\hline & $\mathbf{K}_{\mathbf{4 1}}$ & $\mathbf{K}_{\mathbf{4 2}}$ & $\mathbf{K}_{\mathbf{4 3}}$ \\
\hline $\mathbf{K}_{\mathbf{4 1}}$ & 1 & 3 & 4 \\
$\mathbf{K}_{\mathbf{4 2}}$ & 0.333 & 1 & 2 \\
$\mathbf{K}_{\mathbf{4 3}}$ & 0.25 & 0.5 & 1 \\
\hline
\end{tabular}

$\mathrm{K}_{41}$ : Mean temperature, $\mathrm{K}_{42}$ : Precipitation, $\mathrm{K}_{43}$ : Mean wind speed

Table 8. Calculation of criterion weights

\begin{tabular}{l|c|c|c|c|c|c}
\hline & $\mathbf{K}_{\mathbf{1}}$ & $\mathbf{K}_{\mathbf{2}}$ & $\mathbf{K}_{\mathbf{3}}$ & $\mathbf{K}_{\mathbf{4}}$ & Row total & $\mathbf{w}$ \\
\hline $\mathbf{K}_{\mathbf{1}}$ & 0.596659 & 0.661813 & 0.5 & 0.5 & 2.258472 & 0.564618 \\
$\mathbf{K}_{\mathbf{2}}$ & 0.198687 & 0.220604 & 0.3 & 0.357143 & 1.076436 & 0.269109 \\
$\mathbf{K}_{\mathbf{3}}$ & 0.119332 & 0.073461 & 0.1 & 0.071429 & 0.364220 & 0.091055 \\
$\mathbf{K}_{\mathbf{4}}$ & 0.085322 & 0.044121 & 0.1 & 0.091055 & 0.300872 & 0.075218 \\
\hline
\end{tabular}

w: the matrix's eigenvector

"w" in the last column of Table 8 is the matrix's eigenvector and gives the weight of the criteria by percentage (\%). It is necessary to calculate the consistency of the comparison matrix of the criteria. For a comparison matrix to be consistent, the maximum eigenvalue ( $\chi$ max) must be equal to the dimensions of the matrix (Table 9). Consistency rate greater than $10 \%$ shows that some evaluations are contradictory in the comparisons (Partovi and Hopton, 1994). 
Table 9. Calculation of the consistency of the comparison matrix of criteria

\begin{tabular}{l|c|c|c|c|c|c|c}
\hline & $\mathbf{K}_{\mathbf{1}}$ & $\mathbf{K}_{\mathbf{2}}$ & $\mathbf{K}_{\mathbf{3}}$ & $\mathbf{K}_{\mathbf{4}}$ & $\mathbf{w}$ & $\mathbf{v}$ & $\mathbf{v} / \mathbf{w}$ \\
\hline $\mathbf{K}_{\mathbf{1}}$ & 1 & 3 & 5 & 7 & 0.564618 & 2.353746 & 4.168741 \\
$\mathbf{K}_{\mathbf{2}}$ & 0.333 & 1 & 3 & 5 & 0.269109 & 1.106382 & 4.111278 \\
$\mathbf{K}_{\mathbf{3}}$ & 0.200 & 0.333 & 1 & 1 & 0.091055 & 0.368810 & 4.050408 \\
$\mathbf{K}_{\mathbf{4}}$ & 0.143 & 0.200 & 1 & 1 & 0.075218 & 0.300835 & 3.999510 \\
\hline
\end{tabular}

$\mathrm{w}$ : the matrix's eigenvector, $\mathrm{v}$ : column vector

The previously calculated column vector (eigenvector/priority vector) is obtained by multiplying each row of the comparison criterion. The calculated column vector (v) is divided by the corresponding elements of the column vector (w) to obtain v/w values. The arithmetic mean of the $\mathrm{v} / \mathrm{w}$ column vector gives the largest eigenvalue $(\chi \max =4.082484)$.

$$
\text { Consistency Indicator }=(\chi \max -n) / n-1=(4.082484-4) / 4-1=0.27495
$$

Consistency Ratio = Consistency Indicator $/$ Random index

Random Index for matrices with sizes of 1 to 15 , in the table of random index, $\mathrm{n}=4$ is 0.89 (Saaty, 1990). According to this;

$$
\text { Consistency Ratio }=0.027495 / 0.9=0.03055
$$

Since the consistency ratio is $<0.1$, the matrix can be considered consistent. For the other comparison matrices, the same steps were taken, and the criteria weights and consistency of the criteria were calculated and shown in Table 10.

\begin{tabular}{|c|c|c|c|c|c|c|}
\hline CR & Criteria & Weights & $\mathbf{C R}$ & Sub-criteria & $\begin{array}{l}\text { Local } \\
\text { weight }\end{array}$ & $\begin{array}{c}\text { Overall } \\
\text { weight }\end{array}$ \\
\hline \multirow{13}{*}{0.03} & \multirow{4}{*}{ Human behaviour } & \multirow{4}{*}{0.5646} & \multirow{4}{*}{0.058} & Proximity to settlements & 0.1993 & 0.1125 \\
\hline & & & & Proximity to the roads & 0.6535 & 0.3690 \\
\hline & & & & Proximity to the cultivated areas & 0.0860 & 0.0486 \\
\hline & & & & Proximity to the power lines & 0.0612 & 0.0345 \\
\hline & \multirow{3}{*}{$\begin{array}{c}\text { Structural characteristics } \\
\text { of forests }\end{array}$} & \multirow{3}{*}{0.2691} & \multirow{3}{*}{0.075} & Vegetation type & 0.6194 & 0.1667 \\
\hline & & & & Age of stand development & 0.2842 & 0.0765 \\
\hline & & & & Crown closure & 0.0964 & 0.0259 \\
\hline & \multirow{3}{*}{$\begin{array}{c}\text { Topographic structure of } \\
\text { forests }\end{array}$} & \multirow{3}{*}{0.0911} & \multirow{3}{*}{0.033} & Altitude & 0.6334 & 0.0557 \\
\hline & & & & Slope & 0.1061 & 0.0097 \\
\hline & & & & Aspect & 0.2605 & 0.0237 \\
\hline & \multirow{3}{*}{ Climate data } & \multirow{3}{*}{0.0752} & \multirow{3}{*}{0.016} & $\begin{array}{c}\text { Mean temperature of warmest } \\
\text { quarter }\end{array}$ & 0.6233 & 0.0469 \\
\hline & & & & Precipitation of warmest quarter & 0.2394 & 0.0180 \\
\hline & & & & $\begin{array}{c}\text { Mean wind speed of warmest } \\
\text { quarter }\end{array}$ & 0.1373 & 0.0103 \\
\hline
\end{tabular}

Table 10. Consistency ratios and weights of criteria and sub-criteria

CR: consistency ratio 
Pairwise comparison method is frequently use to estimate the weights of the criteria in the GIS-based multiple-criteria decision-making applications (Malczewski and Rinner, 2015). This method has been tested and applied in land suitability analyses (Stoms et al., 2002; Hamzeh et al., 2016; Bozdağ et al., 2016), environmental impact assessment studies (Bojórquez-Tapia et al., 2002; Rikhtegar et al, 2014) and natural resource management (Hessburg et al., 2013).

In this study, it was concluded that the contribution of human behaviour to fire risk was over 50\% (Table 10). In a study conducted by You et al. (2017), the weight of human activities used to calculate fire risk was found to be the first one among other factors. It is also known that proximity to the road increases the risk of fire. Şentürk (2018) examined the relationship between the locations of forest fire starting points and the roads in Istanbul and found that $427(\sim 65 \%)$ of the 660 fire starting points were located at 0-100 meters from the road. Although climate seems to have a primary effect, it is proposed that it is important to know the proximity of forests to roads and settlements (Sağlam et al., 2008; Wu et al., 2014).

\section{The mapping of fire risk zones}

All geographic layers of the sub criteria in the GIS database were recorded as raster data, and the risk classifications shown in Table 2 were identified. Thus, the spatial distribution of the risk zones belonging to 13 sub criteria was mapped (Figure 4). The criteria and weights determined by AHP were formulated with the help of ArcGIS software's spatial analysis tool and applied to the related geographical layers. The resulting fire risk map was created by using ArcGIS and is presented in Figure 5.

When the spatial distribution of fire risk zones is examined, it is understood that only $0.49 \%$ of forest lands in the field was ranked as very high risk (Table 11). Given that the ratio of the areas with medium and high fire risk is close to $60 \%$ in total, it is possible to suggest that the fire risk of forestlands in the region is relatively high.

The risk assessment conducted for the study area can possible used for the Mediterranean forest ecosystems that have similar forest cover, climate and topographic features. However, it should also be remembered that risk value may change as climate and forest cover change (Jaiswal et al., 2002; Sağlam et al., 2008; Neyişçi, 2009; Küçük et al., 2017). Moreover, we suggest that risk assessment can be performed and risk zones can be mapped for any forest ecosystem if the approach and methodology developed in this study are applied.

In terms of forest fire risks, coniferous species that account for about $80 \%$ of the forests in the field are at higher risk than broad-leaved species. However, it should not be overlooked that broad-leaved forests are also susceptible to fire in the dry season (Kodandapani et al., 2009).

In this study, human behaviour was found to has the highest weight for fire risk. The importance of human behaviours for fire risk has been reported by several studies (Vadrevu et al., 2009; Eskandari and Chuvieco, 2015; Eskandari, 2017). Proximity to forest roads, which is one of the sub-criteria of human behaviours has the highest weight in terms of fire risk (You et al., 2017; Şentürk, 2018). Other researchers also confirmed that vegetation composition (Sağlam et al., 2008; Chuvieco et al., 2012; You et al., 2017), topographic structure (Vadrevu et al., 2009; Çoban and Özdamar, 2014; Eskandari, 2017) and climate (Zumbrunnen et al., 2011; Eskandari, 2017) were important criteria for fire risk. 

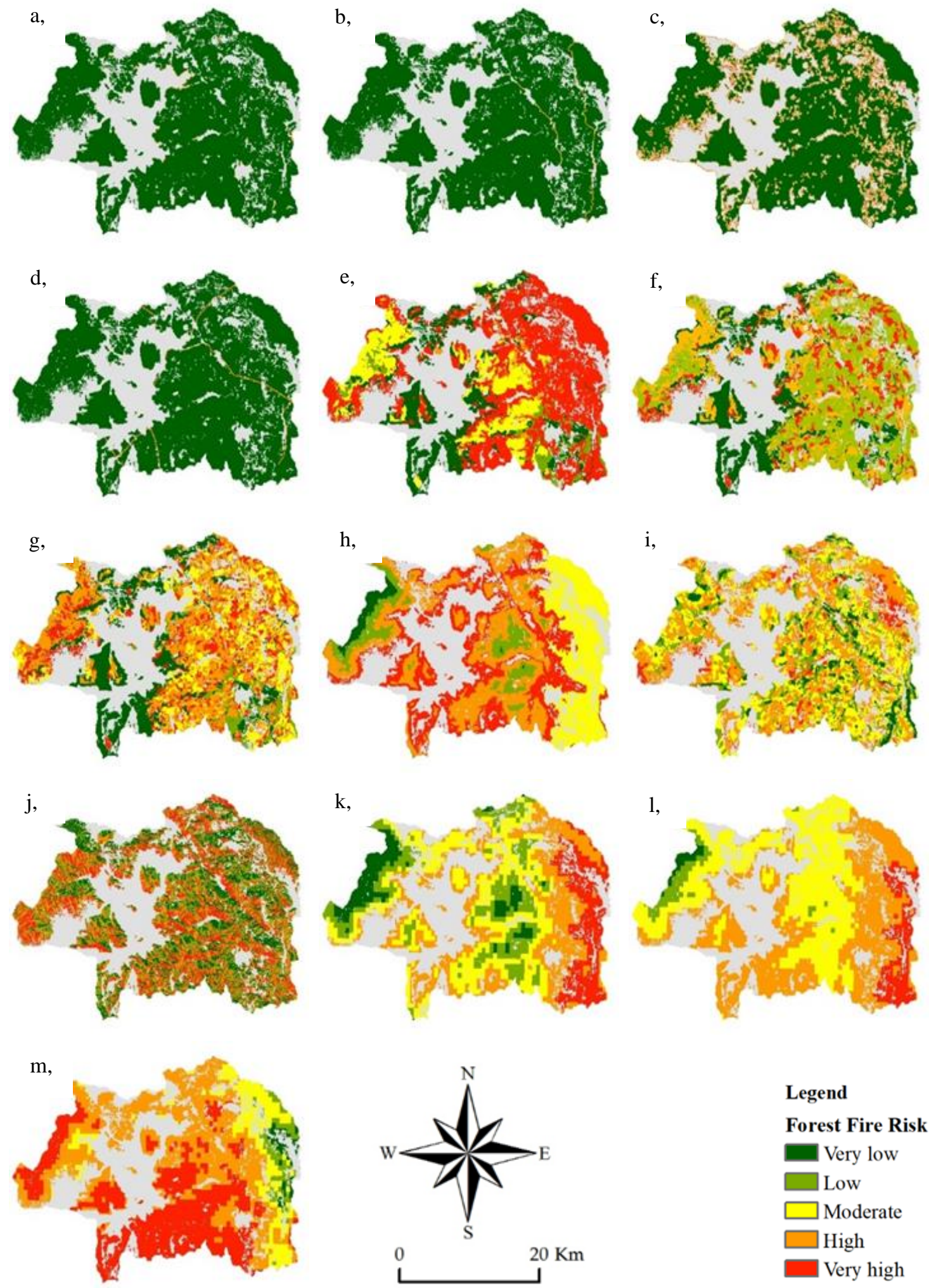

Legend

Forest Fire Risk

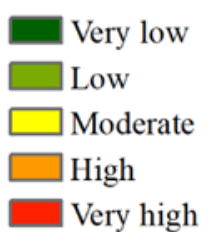

Figure 4. Fire risk zones of the sub-criteria, a) Proximity to settlements, b) Proximity to the road network, $c$ ) Proximity to the cultivated areas, d) Proximity to the power lines, $e$ ) Vegetation type, f) Age of stand development, g) Crown closure, h) Altitude, i) Slope, j) Aspect, $k$ ) Mean temperature of the warmest quarter, l) Precipitation of the warmest quarter, $m$ ) Mean wind speed of the warmest quarter 


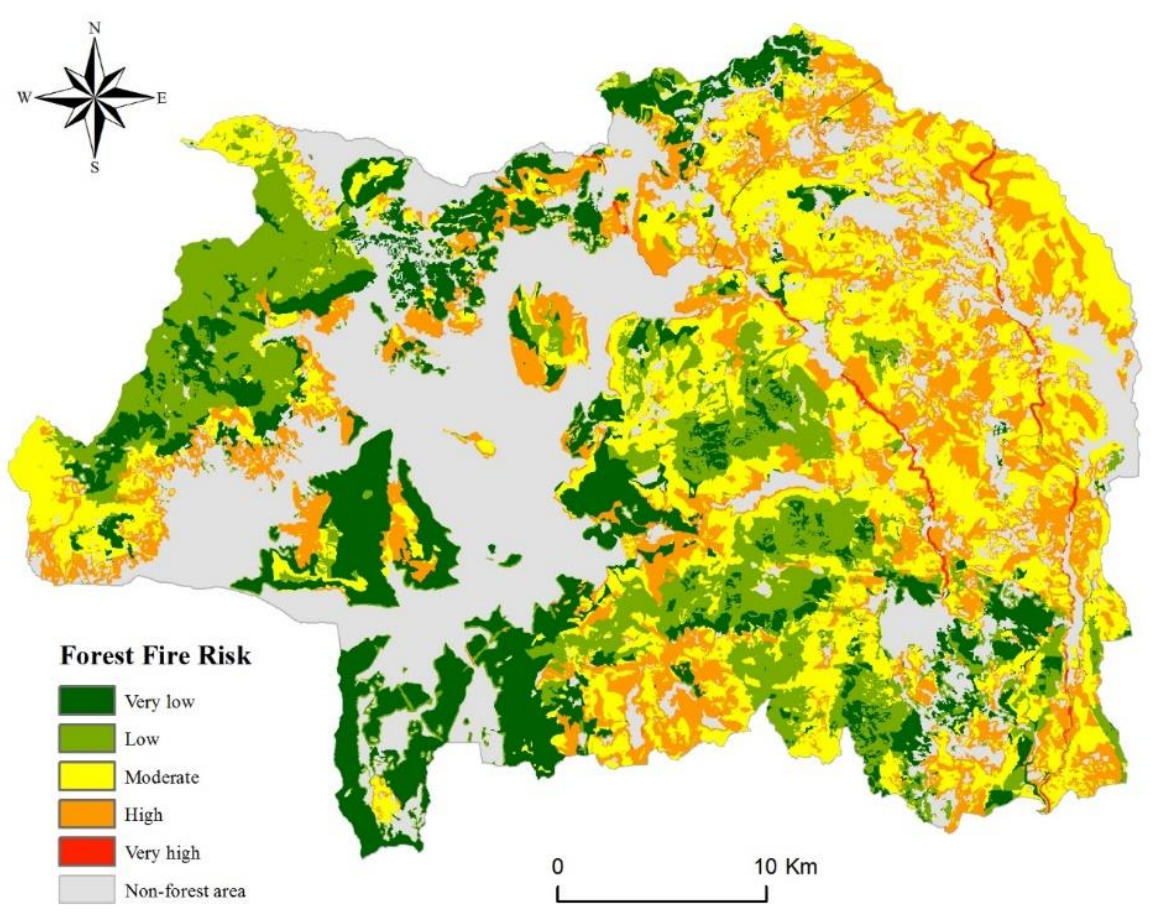

Figure 5. Spatial distribution of fire risk zones

Table 11. Spatial distribution of forest fire risk

\begin{tabular}{|c|c|c|c|c|c|c|c|c|c|c|c|}
\hline \multirow{3}{*}{$\begin{array}{c}\text { Vegetation } \\
\text { type }\end{array}$} & \multicolumn{11}{|c|}{ Forest Fire Risk } \\
\hline & \multicolumn{2}{|c|}{ Very high } & \multicolumn{2}{|c|}{ High } & \multicolumn{2}{|c|}{ Moderate } & \multicolumn{2}{|l|}{ Low } & \multicolumn{2}{|c|}{ Very low } & \multirow{2}{*}{$\begin{array}{c}\text { Total } \\
\text { (ha) }\end{array}$} \\
\hline & ha & $\%$ & ha & $\%$ & ha & $\%$ & ha & $\%$ & ha & $\%$ & \\
\hline $\begin{array}{l}\text { Calabrian } \\
\text { and black } \\
\text { pine }\end{array}$ & 431.10 & 0.82 & 24107.93 & 46.10 & 27242.04 & 52.10 & 192.13 & 0.37 & 317.93 & 0.61 & 52291.13 \\
\hline Coniferous & 17.09 & 0.08 & 418.80 & 2.02 & 4082.92 & 19.70 & 15186.35 & 73.29 & 1016.87 & 4.91 & 20722.03 \\
\hline $\begin{array}{c}\text { Mixed } \\
\text { coniferous- } \\
\text { deciduous } \\
\end{array}$ & 1.73 & 0.03 & 16.14 & 0.31 & 48.80 & 0.95 & 3059.65 & 59.39 & 2025.74 & 39.32 & 5152.06 \\
\hline Deciduous & 3.68 & 0.02 & 49.02 & 0.25 & 78.30 & 0.40 & 1949.93 & 9.92 & 17575.70 & 89.41 & 19656.62 \\
\hline $\begin{array}{c}\text { Shrub } \\
\text { grassland }\end{array}$ & 31.27 & 2.09 & 107.14 & 7.17 & 903.40 & 60.48 & 421.62 & 28.23 & 30.32 & 2.03 & 1493.77 \\
\hline $\begin{array}{l}\text { Other lands } \\
\text { in forest area }\end{array}$ & 8.57 & 0.79 & 80.18 & 7.39 & 45.22 & 4.17 & 37.08 & 3.42 & 914.31 & 84.24 & 1085.36 \\
\hline Total (ha) & 493.44 & & 24779.21 & & 32400.68 & & 20846.76 & & 21880.88 & & 100400.97 \\
\hline
\end{tabular}

\section{Conclusion}

The nature has the power to find ways to compensate the damage caused by horrible catastrophes. Mediterranean forest ecosystems also have the power to cope with fire. Despite that, measures should be taken to fight forest fires as they threaten human life and lead to devastating economic loses, which may in turn lead to extremely dangerous consequence. In addition to several natural variables such as climate, topography, bedrock, vegetation cover, human factor also is also a dominant and adverse factors as regards forest fire. Therefore, it is ideal to manage so many processes from setting forestry 
policies to fight forest fires to planning land use, preserving the structural features of the natural forests, establishing forests suitable for the relevant degraded area and under extreme conditions, ensuring social and cultural development and in this way raising environmental awareness. One of the crucial elements of fight against forest fire is to create fire risk maps. In this way, fire risk zones may provide decision support in planning the fire-fighting organization. Areas at higher fire risk and thus areas where fire may potentially spread and grow can be determined and necessary measures can be taken.

In this study, the fire risk zones of first-degree fire sensitive Mediterranean forest ecosystems in Bucak were identified and mapped. In the total forestland in the study area, $0.5 \%$ of the forests were at a very high fire risk, $25 \%$ were at high risk, while $32 \%$ were at medium risk. This shows that around $60 \%$ of the forestlands are at medium and high forest fire risk. Accordingly, we can say that it is important that forest authority should take measures to prevent forest fires during fire season in this region and raise awareness of people through media and other means of communication. In addition, forest fire reports should contain accurate and detailed information about fire ignition point location and records of all events from the beginning to the end of the fire. We recommend that fire risk maps should be compared with the real fire records and fire risk assessment should be keep up to date.

\section{REFERENCES}

[1] Akay, A. E., Şakar, D. (2009): Using GIS-based decision support system to determine the optimum route to the fire site as soon as possible (in Turkish). - Chamber of Survey and Cadastre Engineers GIS Congress, 02-06, November, İzmir.

[2] Akay, E. E., Şahin, H. (2019): Forest Fire Risk Mapping by using GIS Techniques and AHP Method: A Case Study in Bodrum (Turkey). - European Journal of Forest Engineering 5(1): 25-35.

[3] Akbulak, C., Tatl1, H., Aygün, G., Sağlam, B. (2018): Forest fire risk analysis via integration of GIS, RS and AHP: The Case of Çanakkale, Turkey. - International Journal of Human Sciences 15(4): 2127-2143.

[4] Belhadi, A., Touriki, F. E., El fezazi, S. (2017): Priotizing the solutions of lean implementation SMEs to overcome its barriers: an intergrated fuzzy, AHP-TOPSIS approach. - Journal of Manufacturing Technology Management 28(8): 1115-1139.

[5] Bojórquez-Tapia, L. A., Juarez, L., Cruz-Bello, G. (2002): Integrating fuzzy logic, optimization, and GIS for ecological impact assessments. - Environmental Management 30(3): 418-433.

[6] Bolloju, N. (2001): Aggregation of analytic hierarchy process models based on similarities in decision makers' preferences. - European Journal of Operational Research 128: 499508.

[7] Bozdağ, A., Yavuz, F., Günay, A. S. (2016): AHP and GIS based land suitability analysis for Cihanbeyli (Turkey) County. - Environ Earth Sciences 75(813): 1-15.

[8] Calvo, L., Santalla, S., Valbuena, L., Marcos, E., Tarrega, R., Luis-Calabuig, E. (2008): Post-fire natural regeneration of a Pinus pinaster forest in NW Spain. - Plant Ecology 197: 81-90.

[9] Chang, K. T. (2016): Introduction to geographic information systems (eight edition). McGraw-Hill Education, New York, pp. 10-85.

[10] Chuvieco, E., Aguado, I., Jurdao, S., Pettinari, M. L., Yebra, M., Salas, J., Hantson, S., de la Riva, J., Ibarra, P., Rodrigues, M., Echeverria, M., Azqueta, D., Roman, M. V., Bastarrika, A., Martinez, S., Recondo, C., Zapico, E., Martinez-Vega, F. J. (2012): 
Integrating geospatial information into firerisk assessment. - International Journal of Wildland Fire 23: 606-619.

[11] Çoban, H. O., Özdamar, S. (2014): Mapping forest fire in relation to land-cover and topographic characteristics. - Journal of Environmental Biology 35(1): 217-224.

[12] EC (2017): Forest Fires in Europe 2017. - European Commission, Joint Research Centre (JRC) Technical Reports, Forest Fires in Europe, Middle East and North Africa 2017, 10. EUR 29318 EN.

[13] Eskandari, S., Chuvieco, E. (2015): Fire danger assessment in Iran based on geospatial information. - International Journal of Applied Earth Observation and Geoinformation 42: 57-64.

[14] Eskandari, S. (2017): A new approach for forest fire risk modeling using fuzzy AHP and GIS in Hyrcanian forests of Iran. - Arabian Journal of Geosciences 10(190): 1-13.

[15] Fisher, M. L., Keida, P. (1990): Optimal solution of set covering/partitioning problems using dual heuristics. - Management Science 36(6): 674-688.

[16] Garbolino, E., Sanseverino-Godfrin, V., Hinojos-Mendoza, G. (2017): Reprint of: Describing and predicting of the vegetation development of Corsica due to expected climate change and its impact on forest fire risk evolution. - Safety Science 97: 81-87.

[17] García-Llamas, P., Suárez-Seoane, S., Taboada, A., Fernández-Manso, A., Quintano, C., Fernández-García, V., Fernández-Guisuraga, J. M., Marcos, E., Calvo, L. (2019): Environmental drivers of fire severity in extreme fire events that affect Mediterranean pine forest ecosystems. - Forest Ecology and Management 433: 24-32.

[18] GDF (2019): Forestry statistics. - Publications of General Directorate of Forestry. https://www.ogm.gov.tr/ekutuphane/Istatistikler/Forms/AllItems.aspx. (accessed 09.06.2019). (in Turkish).

[19] González-De Vega, S., De las Heras, J., Moya, D. (2016): Resilience of Mediterranean terrestrial ecosystems and fire severity in semiarid areas: Responses of Aleppo pine forests in the short, mid and long term. - Science of the Total Environment 573: 1171-1177.

[20] Guarini, M. R., Battisti, F., Chiovitti, A. A. (2018): Methodology for the Selection of MultiCriteria Decision Analysis Methods in Real Estate and Land Management Processes. Sustainability 10(507): 1-28.

[21] Güngöroğlu, C. (2017): Determination of forest fire risk with fuzzy analytic hierarchy process and its mapping with the application of GIS: The case of Turkey/Çakırlar. - Human and Ecological Risk Assessment: An International Journal 23(2): 388-406.

[22] Hamzeh, S., Mokarram, M., Haratian, A., Bartholomeus, H., Ligtenberg, A., Bregt, A. K. (2016): Feature Selection as a Time and Cost-Saving Approach for Land Suitability Classification (Case Study of Shavur Plain, Iran). - Agriculture 6(52): 1-13.

[23] Hessburg, P. F., Reynolds, K. M., Salter, R. B., Dickinson, J. D., Gaines, W. L., Harrod, R. J. (2013): Landscape evaluation for restoration planning on the Okanogan-Wenatchee National Forest USA. - Sustainability 5: 805-840.

[24] IRDF (2019): Forest fire statistics (unpublished fire inventory forms, 2008-2018). - Isparta Regional Directorate of Forestry, Isparta, Turkey.

[25] Ishizaka, A., Nguyen, N. H. (2013): Calibrated Fuzzy AHP for current bank account selection. - Expert Systems with Aplications 40(9): 3375-3783.

[26] Jain, B. A., Nag, B. N. (1996): A Decision-Support Model For Investment Decisions in New Ventures. - European Journal of Operational Research 90(3): 473-486.

[27] Jaiswal, R. K., Mukherjee, S., Raju, D. K., Saxena, R. (2002): Forest fire risk zone mapping from satellite imagery and GIS. - International Journal of Applied Earth Observation and Geoinformation 4: 1-10.

[28] Jenks, G. F., Caspall, F. C. (1971): Error on choroplethic maps: definition, measurement, reduction. - Annals of the Association of American Geographers 61(2): 217-244.

[29] Kodandapani, N., Cochrane, M. A., Sukumar, R. (2009): Forest fire regimes and their ecological effects in seasonally dry tropical ecosystems in the Western Ghats, India. - In: 
Cochrane, M. A. (ed.) Tropical Fire Ecology: Climate change, Land use and Ecosystem Dynamics. Springer Praxis Books, 335-354.

[30] Korkmaz, M. (2004): Determination of optimum fire observation points using cluster covering model. - Süleyman Demirel University, Journal of Forestry Faculty A(1): 37-49. (in Turkish).

[31] Kumar, D., Gark, C. P. (2017): Evaluating Sustainable Supply Chain Indicators Using Fuzzy AHP Case of Indian Automotive Industry. - Benchmarking; An International Journal 24(6): 1742-1766.

[32] Kuruüzüm, A., Atsan, N. (2001): Analytical Hierarchy Method and Applications in Business. - Akdeniz İ.İ.B.F. Journal 1: 83-105. (in Turkish).

[33] Küçük, Ö., Topaloğlu, Ö., Altunel, A. O., Çetin, M. (2017): Visibility analysis of fire lookout towers in the Boyabat State Forest Enterprise in Turkey. - Environmental Monitoring and Assessment 189(329): 2-18.

[34] Malczewski, J., Rinner, C. (2015): Multicriteria Decision Analysis in Geographic Information Science. - Springer-Verlag Berlin Heidelberg. pp. 23-50.

[35] McKenzie, D., Shankar, U., Keane, R. E., Stavros, E. N., Heilman, W. E., Fox, D. G., Riebau, A. C. (2014): Smoke consequences of new wildfire regimes driven by climate change. - Earth's Future 2: 35-59.

[36] Naderpour, M., Rizeei, H. M., Khakzad, N., Pradhan, B. (2019): Forest fire induced Natech risk assessment: A survey of geospatial technologies. - Reliability Engineering and System Safety 191: 106558.

[37] Neyişçi, T., Ayaşlıgil, Y., Ayaşlıgil, T., Sönmezış1k, S. (1996): Principles of afforestration for fire resistant forests. - Project report, The Scientific and Technological Research Council of Turkey, Project number: TOGTAG-1342, Antalya. (in Turkish).

[38] Neyişçi, T. (2009): Flammable management as a means of forest fire management. $-1^{\text {st }}$ Forest Fire Fighting Symposium, 07-10 January, Antalya, pp. 249-255. (in Turkish).

[39] Partovi, F. Y., Hopton, W. E. (1994): The analytic hierarchy process as applied to two types of inventory problems. - Productions and Inventory Management Journal 35(1): 13-19.

[40] Pausas, J. G., Vallejo, V. R. (1999): The role of fire in European Mediterranean ecosystems. - In: Chuvieco, E. (ed.) Remote Sensing of large wildfires in the European Mediterranean basin. Berlin, Springer-Verlag, pp. 3-16.

[41] Rikhtegar, N., Mansouri, N., Oroumieh, A. A., Yazdani-Chamzini, A., Zavadskas, E. K., Kildienè, S. (2014): Environmental impact assessment based on group decision-making methods in mining projects. - Economic Research-Ekonomska Istraživanja 27(1): 378-392.

[42] Saaty, T. L. (1980): The Analytic Hierarchy Process. - McGraw-Hill, New York, pp. 5070.

[43] Saaty, T. L. (1990): How to make a decision: The Analytic Hierarchy Process. - European Journal of Operation Research 48: 9-26.

[44] Saaty, T. L., Vargas, L. G. (2012): Models, Methods, Concepts \& Applications of the Analytic Hierarchy Process. $-2^{\text {nd }}$ Edition, Springer Science+Business Media New York, pp. 63-70.

[45] Saaty, R. W., Saaty, T. L. (2019): Decision Making in Complex Environments. - Available online: https://superdecisions.com/sd_resources/v28_man02.pdf (Accessed 29.08.2019).

[46] Sağlam, B., Bilgili, E., Durmaz, B. D., Kadıoğulları, A., Küçük, Ö. (2008): SpatioTemporal analysis of forest fire risk and danger using LANDSAT imagery. - Sensors 8: 3970-3987.

[47] Simon, H. A. (1960): The New Science of Management Decisions. - New York: Harper and Row, pp. 3-21.

[48] Stoms, D. M., McDonald, J. M., Davis, F. W. (2002): Fuzzy assessment of land suitability for scientific research reserves. - Environmental Management 29(4): 545-558.

[49] Şentürk, N. (2018): Assessment of relationship between locations and distances to roadside of forest fires in Istanbul, Turkey. - Applied Ecology and Environmental Research 16(5): 6195-6204. 
[50] USGS (2019): NASA SRTM Version 3.0 "1 Arc second" data. - United States Geological Survey, 2017, https://gdex.cr.usgs.gov/gdex/ (accessed 07.06.2019).

[51] Vadrevu, K. P., Eaturu, A., Badarinath, K. V. S. (2010): Fire risk evaluation using multicriteria analysis-a case study. Environment Monitoring and Assessment 166: 223-239.

[52] Van den Honert, R. C., Lootsma, F. A. (1996): Group preference aggregation in the multiplicative AHP - the model of the group decision process and Pareto optimality. European Journal of Operational Research 96: 363-370.

[53] Worldclim (2019): Global Climate Data, Version 2 (Free climate data for ecological modeling and GIS). - http://worldclim.org/version2 (accessed 07.06.2019).

[54] Wu, Z., He, H. S., Yang, J., Liu, Z., Liang, Y. (2014): Relative effects of climatic and local factors on fire occurrence in boreal forest landscapes of northeastern China. - Science of The Total Environment 493: 472-480.

[55] Yomralıoğlu, T. (2015): Geographic Information Systems. $-6^{\text {th }}$ Edition, Akademi Press, Trabzon, Turkey, pp. 45-61. (in Turkish).

[56] You, W., Lin, L., Wu, L., Ji, Z., Yu, J., Zhu, J., Fan, Y., He, D. (2017): Geographical information system-based forest fire risk assessment integrating national forest inventory data and analysis of its spatiotemporal variability. - Ecological Indicators 77: 176-184.

[57] Zumbrunnen, T., Pezzatti, G. B., Menéndez, P., Bugmann, H., Bürgi, M., Conedera, M. (2011): Weather and human impacts on forest fires: 100 years of fire history in two climatic regions of Switzerland. - Forest Ecology and Management 261: 2188-2199. 